\title{
Trends in catch rates of sea turtles in North Carolina, USA
}

\author{
Sheryan P. Epperly ${ }^{1, *}$, Joanne Braun-McNeill ${ }^{2}$, Paul M. Richards ${ }^{1}$ \\ ${ }^{1}$ NOAA, National Marine Fisheries Service, Southeast Fisheries Science Center, 75 Virginia Beach Dr., Miami, \\ Florida 33149, USA \\ ${ }^{2}$ NOAA, National Marine Fisheries Service, Southeast Fisheries Science Center, 101 Pivers Island Rd., Beaufort, \\ North Carolina 28516, USA
}

\begin{abstract}
Sea turtles captured in pound nets during the autumn and early winter in the PamlicoAlbermarle Estuarine Complex, North Carolina, USA, were sampled 1995-1997 and 2001-2003 to monitor trends in catch rates during their autumn emigration from the temperate sounds. Juvenile loggerhead turtles Caretta caretta were the most frequent species encountered, followed by green turtles Chelonia mydas and Kemp's ridley turtles Lepidochelys kempii. Several different subpopulations with origins throughout the western North Atlantic were represented on these foraging grounds. The catch rates of loggerhead turtles increased significantly at a rate of $13 \% \mathrm{yr}^{-1}$. Despite annual increases in the major contributing nesting beach populations in excess of $10 \% \mathrm{yr}^{-1}$, we did not detect a trend in catch rates for either green or Kemp's ridley turtles, perhaps due to low statistical power. There was a significant increase in size of loggerhead turtles over time. We also detected a significant difference in annual size distributions of green and Kemp's ridley sea turtles, but there was no discernable pattern. We conclude that long-term studies on the sea turtles' foraging grounds, at multiple sites, are needed to monitor the status of sea turtle populations.
\end{abstract}

KEY WORDS: Sea turtles $\cdot$ Caretta $\cdot$ Chelonia $\cdot$ Lepidochelys $\cdot$ Catch rates $\cdot$ Trends

\section{INTRODUCTION}

Sea turtles are long-lived, late maturing species that spend virtually all their lives in marine waters. All but one species are listed globally as endangered or critically endangered (IUCN 2006). Historically, most sea turtle research has focused on the brief emergences of nesting females. However, unless the populations are at equilibrium, counts of nesting turtles are an imperfect index of the current status of the entire population because such counts reflect nest production decades earlier. The effects of low production, an emerging source of mortality, or conversely, the removal of a source of mortality may not be detected on the beaches for decades. A few long-term studies of sea turtles on foraging grounds have provided valuable insight into population structure and trends. For example, work in Australia (Chaloupka \& Limpus 2001) and the
Bahamas (Bjorndal et al. 2005) provided information on trends in the abundance of green turtle Chelonia mydas populations in 2 ocean basins.

Sea turtle life histories are complex and comprise several life stages. Over their lifetime, sea turtles may inhabit virtually an entire ocean basin, including oceanic and coastal waters. Furthermore, sea turtle subpopulations each potentially have a different abundance trend and apparently mix non-randomly on the neritic foraging grounds (Broderick et al. 1994, Sears et al. 1995, Bolten et al. 1998, Bowen et al. 2004). Thus, multiple foraging grounds, with potentially differential demographics, contribute to a given nesting assemblage. Given such complexity, it is unlikely that estimating absolute abundance would be possible. Instead, studies have focused on estimating local abundance, indices of abundance, and trends of those measures using catch-per-unit-effort (CPUE), distance 
(transects), and mark-recapture analyses (e.g. Epperly et al. 1995a, Leon \& Diez 1999, Chaloupka \& Limpus 2001, Bjorndal et al. 2005, Ehrhart et al. 2007).

The Pamlico-Albemarle Estuarine Complex of eastern North America is an important developmental and foraging habitat for loggerhead Caretta caretta, green Chelonia mydas, and Kemp's ridley Lepidochelys kempii sea turtles (Epperly et al. 1995b). These foraging ground turtles represent several different subpopulations with origins throughout the western North Atlantic (Bass et al. 2004, 2006). Relatively large numbers of turtles are captured in pound nets set behind the barrier islands of the Complex (Epperly et al. 1995b). We present sea turtle CPUE results for these pound nets and examine trends in CPUE and size frequency distributions in order to evaluate the status of the stocks in the region.

\section{BACKGROUND}

Study area. The Pamlico-Albemarle Estuarine Complex is the largest estuarine system in the southeastern United States and is the third largest system in North America (Gross 1972). The Complex, located in North Carolina (NC), is a series of coastal lagoons, separated from the ocean by barrier islands (Fig. 1). It comprises 7 sounds: Albemarle, Currituck, Roanoke, Croatan,

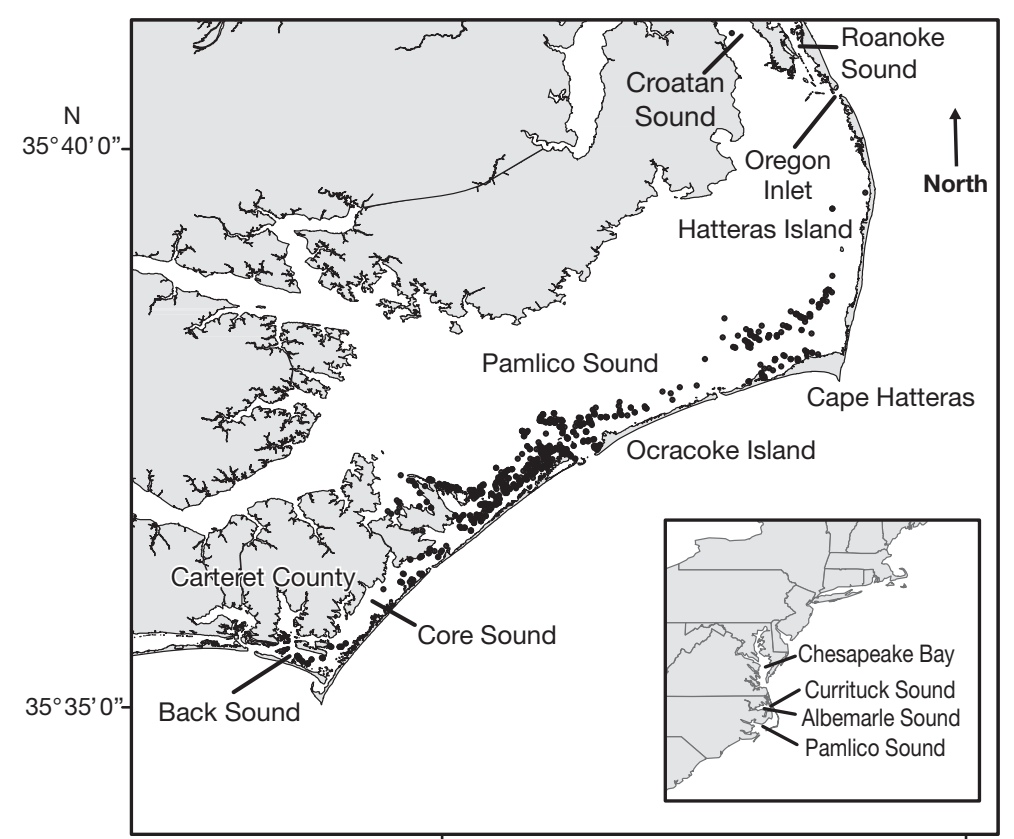

$76^{\circ} 18^{\prime} 0^{\prime \prime} \mathrm{W}$

$75^{\circ} 17^{\prime} 0^{\prime \prime}$

Fig. 1. Pamlico-Albemarle Estuarine Complex, North Carolina, USA, showing the locations of sets sampled from 1995 to 1997 and 2001 to 2003. Albemarle and Currituck Sounds are to the north and are not shown on the enlarged map of the study area
Pamlico, Core, and Back. The physiographic and hydrologic regimes create diverse estuarine habitats: open waters of the sounds, deeper central basins, embayments and tributary creeks, and shallow shelf areas where seagrasses abound. The area encompasses important developmental habitat for many estuarine and marine species and supports many recreational and commercial fisheries (Ross \& Epperly 1985).

Pound net fisheries. The pound net was introduced in NC in the late 19th century (True 1887). Several different pound net fisheries occur in the Pamlico-Albermarle Estuarine Complex: the oldest is the late winterearly spring fishery for anadromous clupeid fishes, prosecuted well upstream, particularly in Albemarle Sound (True 1887, NCDMF 2007); a summer fishery that targets sciaenids and other marine fishes, concentrated mainly in Pamlico Sound (Higgins \& Pearson 1928); and an autumn fishery that occurs in the eastern portion of the Complex, targeting southern flounder Paralichthyes lethostigma (NCDMF 2005). We worked cooperatively with the autumn flounder fishery, where pound net use is the greatest, to gain access to sea turtles.

While the size and number of nets vary by fishery, there are always 3 basic components of a pound net: a lead, a heart (named for its shape), and a pound (Fig. 2). In the case of the autumn flounder fishery, the leads are vertical walls of netting, usually 135 to $275 \mathrm{~m}$ in length. These leads end in the opening of the heart. The tunnel, a funnel-shaped area in the rear of the heart with a rectangular opening 70 to $90 \mathrm{~cm}$ and reinforced with iron rebar, connects the heart to the pound. The pounds are usually 7 to $9 \mathrm{~m}$ to a side, 2.4 to $4.3 \mathrm{~m}$ deep, and have a mesh floor. The stretch mesh size of the lead usually is 15 to $20 \mathrm{~cm}$; the mesh of the heart and tunnel usually is 10 to $13 \mathrm{~cm}$, and the mesh in the pound usually is $10 \mathrm{~cm}$. Multiple pound nets frequently are linked together, usually in line, and collectively are named a 'set'. Fish and turtles are intercepted by the lead and swim parallel to it, entering the heart, where they are funneled into the pound. Usually, turtles can surface in the pound to breathe, and therefore mortality is infrequent. Stakes are left in place year-round, but nets are attached only during the fishing season. Sets are registered by the State (North Carolina Marine Fisheries Commission 2007) and ownership may be transferred, but abandonment or addition of new sets occurs only rarely within a fishing season. The nets are fished by a crew of 2 to 3 persons; frequently $(\sim 20 \%) 2$ owners fish together as a team, fishing both individuals' nets during a trip. These 


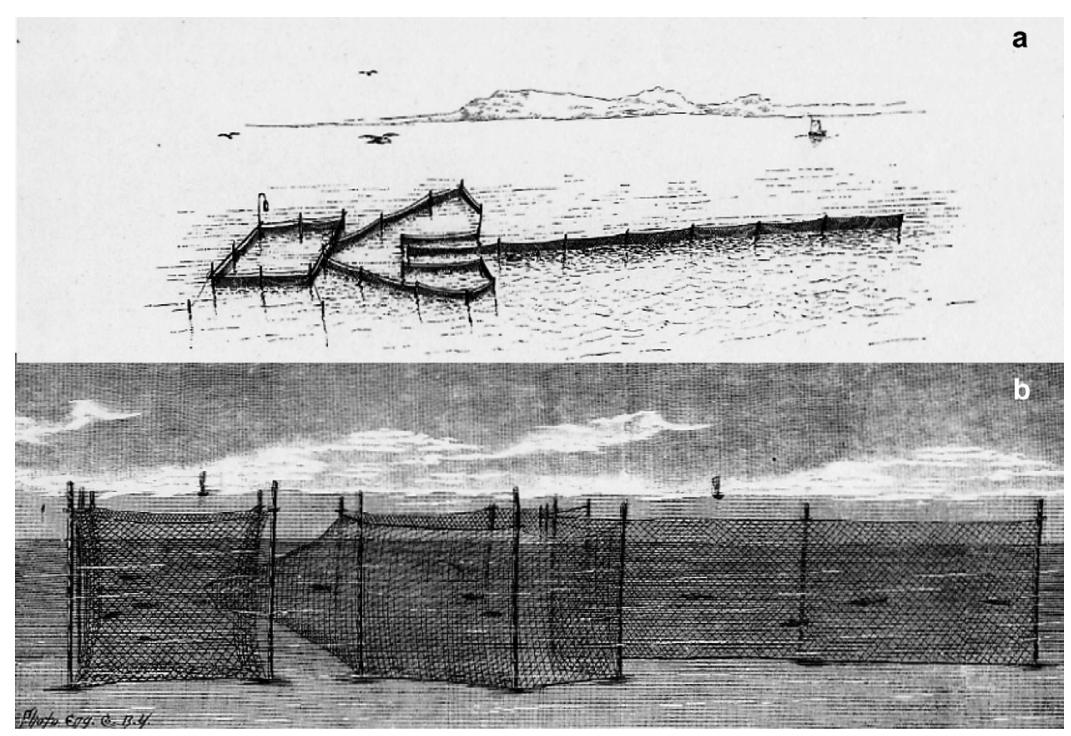

Fig. 2. (a) Aerial and (b) lateral views of a generalized pound net. Figures are reproduced from Goode (1887, Plates 172 and 175, respectively) and were drawn by L. Kumlien

alliances usually are permanent within a season, but may vary among seasons.

Flounder fishermen begin placing their pound nets in the water during September, and continue adding nets and fishing them more frequently as the season progresses. Catches peak in November, following weather events that motivate the emigration of migratory species, including turtles. By December, flounder catch rates decline. Consequently, the nets are fished less frequently, and fishermen start to remove their nets. This fishery has existed since the early 1900s and perhaps before (N. Peele pers. comm.). Except for the introduction of gasoline outboard motors and pumps (used to put the stakes in place), this artisanal fishery has not incorporated any modern technologies.

\section{MATERIALS AND METHODS}

Our sampling occurred for 3 consecutive years (1995 to 1997), followed by 3 years with no sampling, and then 3 additional years of sampling (2001 to 2003). Flounder fishermen were chosen at random each week from the State's registration file. Each of 4 observers attempted to sample 3 fishing trips each week, beginning mid-September (Week 1) and ending midDecember (Week 13). All nets fished by the selected fisherman and his crew that day were sampled, even if some of the sets fished belonged to a fisherman not selected (e.g. belonged to a member of the crew who also had registered nets). One observer worked with fishermen from Hatteras Island, one with fishermen from Ocracoke Island, and 2 with fishermen from Carteret County (Fig. 1), where most fishermen were based. Fishermen whose sets were located south of Oregon Inlet were selected because preliminary data indicated that turtles in the sounds to the north emigrated prior to our sampling period (NOAA Fisheries unpubl. data). Weekly aerial surveys were conducted to count sets and pounds to determine the proportion of the total fishing effort that we were sampling.

The location of each sampled pound was recorded using hand-held GPS units (Fig. 1). Calibrated thermometers were used to record surface water temperature at the first pound net fished each day. Soak time, the number of days since the pound nets were last fished, was recorded as a measure of nominal fishing effort. After turtles were brought on board, blood was drawn and tissue biopsies were taken for genetic analysis (Bass et al. 2004, 2006) and sex determination (Braun-McNeill et al. 2007). Turtles were marked (2 Inconel tags in the rear flippers and one $125 \mathrm{kHz}$ PIT tag in a front flipper) to determine the actual number of individuals caught. Turtles less than $25 \mathrm{~cm}$ straight carapace length (SCL) were not tagged with Inconel tags. Triple tagging in this manner ensured negligible $(0.005 \%)$ total mark loss (Braun-McNeill et al. 2003).

Standard straight-line and curved carapace lengths and widths were measured to identify the life stages being caught and to allow us to detect shifts in size distributions within the sampled populations. Mean sizes and size frequency distributions were compared using parametric (ANOVA) and non-parametric statistics (Kolmogorov-Smirnov, KS), respectively (SAS ${ }^{\circledast}$ Ver. 9.1 NPAR1WAY Procedure).

To estimate an annual number of individual turtles caught by species, all within-year recaptures of turtles were removed from the analysis, but recaptures between years were retained and treated as unique captures. We assumed that turtles that we were unable to mark or where we could not determine if a mark was present (e.g. escaped or too large to bring on board) were only captured once within each year, and we thus retained them in the analysis as if they were uniquely marked.

We used sets as the sampling unit in the analysis, as we could assume independence of sets, but not of pounds, which were linked within a set. To account for 

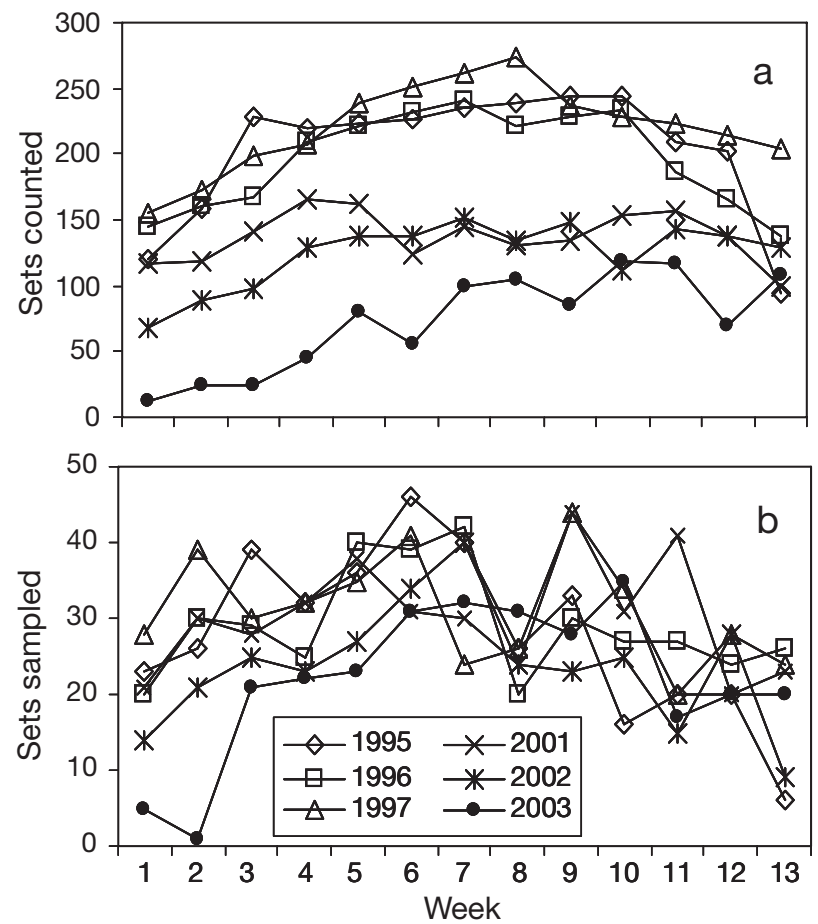

Fig. 3. Weekly (a) fishing effort (sets counted) and (b) sampling effort (sets sampled) in the North Carolina autumn pound net fishery south of Oregon Inlet, September to December 1995 to 1997 and 2001 to 2003. Sets were counted during weekly aerial surveys of the Pamlico-Albemarle Estuarine Complex. Week 1 begins in mid-September (Sep 14

to 17) and Week 13 ends in mid-December (Dec 13-16)

the size of the sets and for the duration each pound was fished, CPUE was defined as catch per pound net-soak day and was calculated by dividing the number of captures in the sampled portion of a set by the sum of all the soak days for sampled pounds in that set. Due to the large number of zeros in the data set (sets with no captures) the delta-estimator method (Pennington 1983) was used to estimate the mean and variance of turtles captured per pound net-soak day (i.e. CPUE). Approximate 95\% confidence intervals (95\% CI) were calculated assuming a log-normal distribution of the CPUE. CPUEs, means, variation, coefficient of variations $(\mathrm{CV})$ and $\mathrm{CIs}$ were calculated using MATLAB (Ver. 7.0).

Linear regression (SAS ${ }^{\circledR}$ Ver. 9.1) was used to test for a significant change in annual mean CPUEs for each species. If no trend was detected, a power analysis was conducted using TRENDS (Gerrodette 1987, 1993) to determine both our statistical power and the number of sampling intervals needed to realize a power $>0.9$ and thus detect a trend comparable to those reported on the nesting beaches. In the power analysis, we used the mean of the 6 annual CVs in a 2-tailed test, setting $\alpha=0.05$.

\section{RESULTS}

Fishing effort usually peaked during Weeks 7 to 10 , with as many as 273 sets (872 pound nets) counted south of Oregon Inlet in 1 wk (Fig. 3a). Fishing effort during 2001 to 2003 was lower than in the earlier period of 1995 to 1997, especially in 2003 when a hurricane severely impacted the area. We sampled 6 to $55 \%$ of the sets in any given week (5 to $48 \%$ of the pounds) and 14 to $30 \%$ of the sets (12 to $29 \%$ of the pounds) within a year (Fig. 3b). Pound nets per set ranged from 1 to 22, with a median of 2 and a mean of 2.9 (SD = 2.3). Mean surface water temperatures decreased over the autumn sampling period, ranging from $23.4-25.8^{\circ} \mathrm{C}$ in Week 1 to $6.8-15.9^{\circ} \mathrm{C}$ in Week 13 .

We observed a total of 1303 captures of sea turtles (Table 1, Fig. 4). Of the 2167 total sets examined, 656 sets captured turtles. We captured loggerhead sea turtles in 541 sets, green turtles in 207 sets, and Kemp's ridley turtles in 59 sets. Catches early in the sampling season were relatively low, but as the season pro-

Table 1. Caretta caretta, Chelonia mydas, and Lepidochelys kempii. Total number of loggerhead, green, and Kemp's ridley sea turtles captured, number of recaptures within the year, and the estimated total unique individuals (total captured - recaptures) in the North Carolina pound net fishery, September to December 1995 to 1997 and 2001 to 2003; recaptures between years $(\mathrm{n}=11)$ were retained. Estimated total unique individuals include 27 loggerhead turtles that escaped before we could determine if they were marked

\begin{tabular}{|c|c|c|c|}
\hline Year & $\begin{array}{c}\text { Total } \\
\text { captured }\end{array}$ & $\begin{array}{l}\text { Recaptures } \\
\text { within year }\end{array}$ & $\begin{array}{c}\text { Estimated total } \\
\text { unique individuals }\end{array}$ \\
\hline \multicolumn{4}{|c|}{ Caretta caretta } \\
\hline 1995 & 111 & 9 & 102 \\
\hline 1996 & 97 & 5 & 92 \\
\hline 1997 & 156 & 3 & 153 \\
\hline 2001 & 258 & 33 & 225 \\
\hline 2002 & 207 & 16 & 191 \\
\hline 2003 & 158 & 11 & 147 \\
\hline Total & 987 & 77 & 910 \\
\hline \multicolumn{4}{|c|}{ Chelonia mydas } \\
\hline 1995 & 42 & 1 & 41 \\
\hline 1996 & 33 & 0 & 33 \\
\hline 1997 & 31 & 1 & 30 \\
\hline 2001 & 67 & 4 & 63 \\
\hline 2002 & 44 & 0 & 44 \\
\hline 2003 & 29 & 0 & 29 \\
\hline Total & 246 & 6 & 240 \\
\hline \multicolumn{4}{|c|}{ Lepidochelys kempii } \\
\hline 1995 & 1 & 0 & 1 \\
\hline 1996 & 4 & 1 & 3 \\
\hline 1997 & 10 & 0 & 10 \\
\hline 2001 & 30 & 1 & 29 \\
\hline 2002 & 18 & 0 & 18 \\
\hline 2003 & 7 & 0 & 7 \\
\hline Total & 70 & 2 & 68 \\
\hline
\end{tabular}



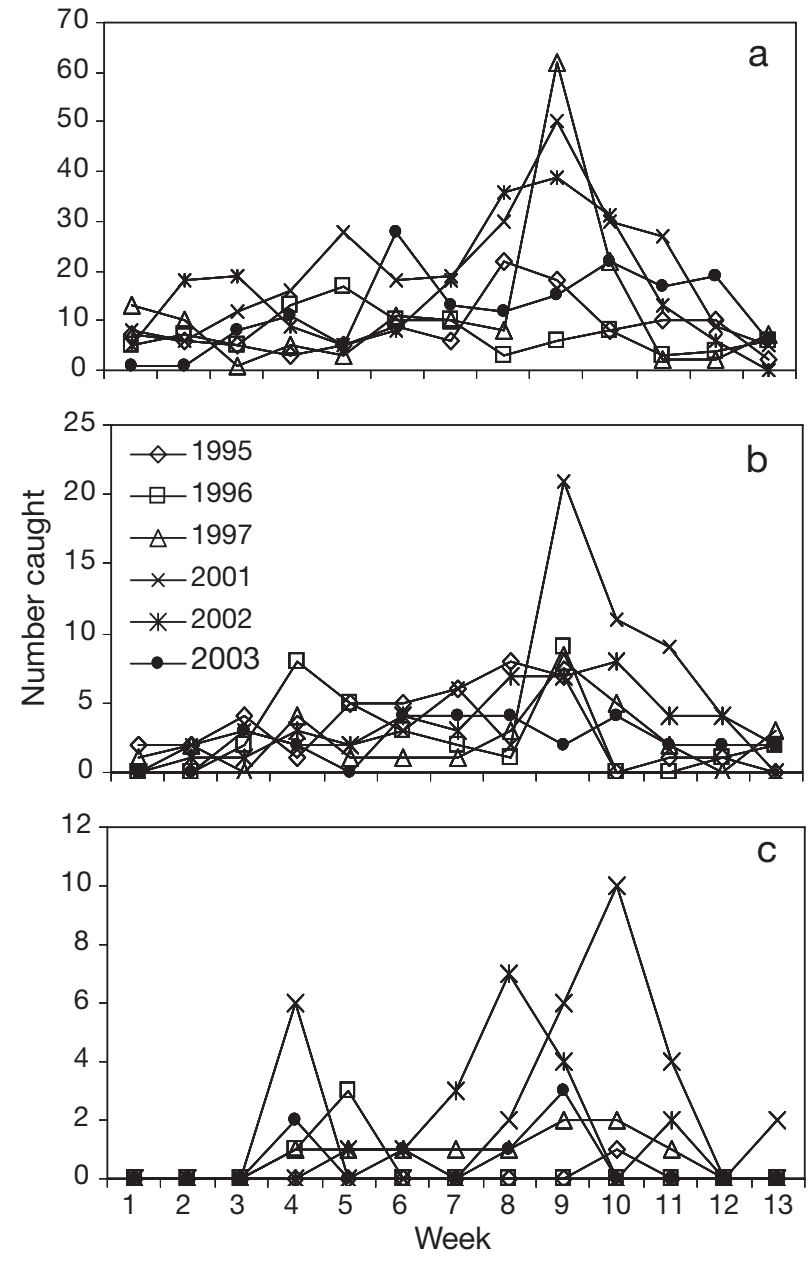

Fig. 4. Caretta caretta, Chelonia mydas, and Lepidochelys kempii. Weekly catches of (a) loggerhead, (b) green, and (c) Kemp's ridley sea turtles, September to December 1995 to 1997 and 2001 to 2003 in eastern Pamlico, Core, and Back Sounds. Week 1 begins in mid-September (Sep 14 to 17) and Week 13 ends in mid-December (Dec 13 to 16). Note the different scales on the $y$-axes

gressed (and water temperature dropped) the catches increased (Fig. 4). By the end of the season, catches decreased, presumably the result of autumn emigration. Throughout the course of the study, we observed 2 dead loggerhead turtles, 14 dead green turtles, and 1 dead Kemp's ridley turtle. The catches represented a total of 910 unique captures of loggerhead turtles (Fig. 4a), 240 green turtles (Fig. 4b), and 68 Kemp's ridley turtles (Fig. 4c, Table 1). We used our estimates of unique captures for all subsequent analyses.

Loggerhead turtles ranged in size from 41.4 to $102.5 \mathrm{~cm} \mathrm{SCL}$, with a median of $61.6 \mathrm{~cm}$ and a mean of $61.2 \mathrm{~cm}(\mathrm{SD}=7.42, \mathrm{n}=866$ ) (Fig. 5). Mean size and the size distribution varied significantly among years (ANOVA, $F=12.4532, \mathrm{p}<0.0001, \mathrm{df}=5 ; \mathrm{KS}=0.1342$, $\mathrm{p}<0.01, \mathrm{n}=866)$. Turtles captured during the later

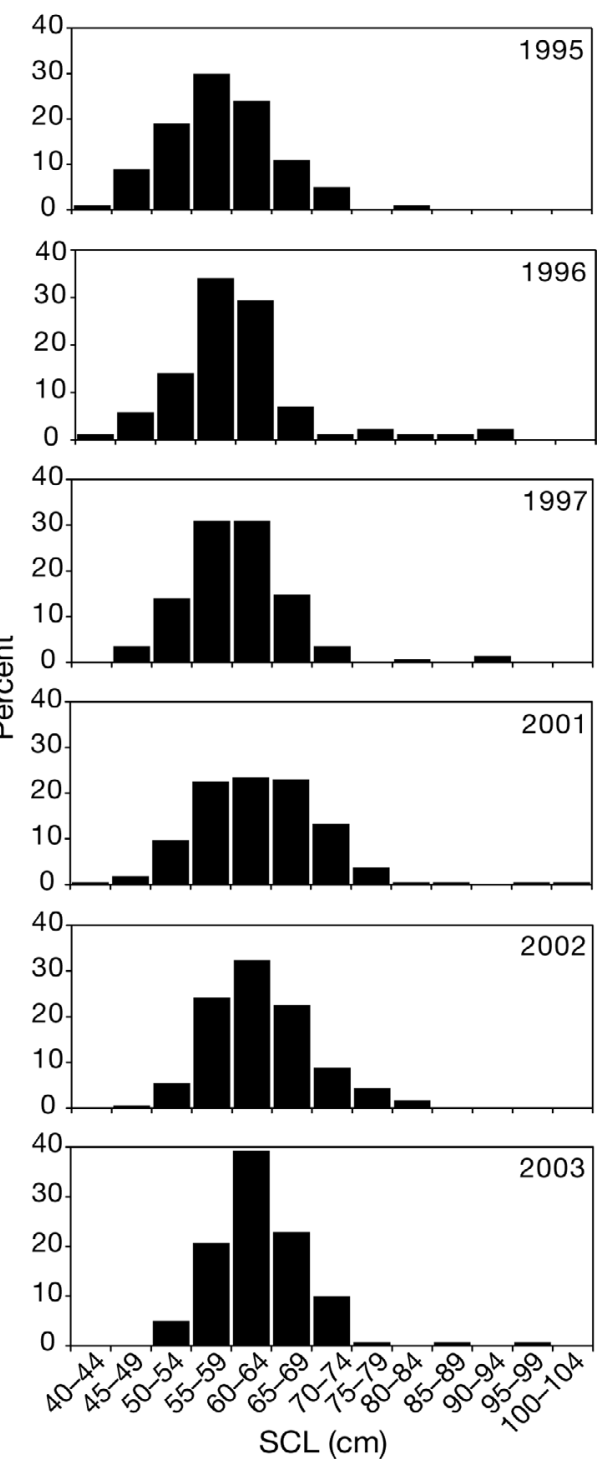

Fig. 5. Caretta caretta. Annual size frequency distributions of loggerhead sea turtles captured September to December in eastern Pamlico, Core, and Back Sounds, $1995(\mathrm{n}=100), 1996$ $(\mathrm{n}=85), 1997(\mathrm{n}=142), 2001(\mathrm{n}=217), 2002(\mathrm{n}=182)$, and $2003(n=140)$. Approximate average size of putative first time nesters (defined as unmarked turtles on beaches with saturation tagging, some of which may have been previously undetected nesters) is $90 \mathrm{~cm}$ (NMFS SEFSC 2001). SCL: straight carapace length

years were larger than those captured during the earlier years (ANOVA, $F=55.7820, \mathrm{p}<0.0001, \mathrm{df}=1$ ). The shift is most apparent in 2 size classes: $55-59 \mathrm{~cm}$ turtles were the dominant size class in the first couple of years, but this shifted to $60-64 \mathrm{~cm}$ for the last $2 \mathrm{yr}$.

Green turtles ranged in size from 20.6 to $76.7 \mathrm{~cm}$ $\mathrm{SCL}$, with a median of $32.2 \mathrm{~cm}$ and a mean of $33.6 \mathrm{~cm}$ ( $\mathrm{SD}=10.26, \mathrm{n}=226$ ) (Fig. 6). While the mean size did not vary among years (ANOVA, $F=1.1546, \mathrm{p}=0.3329$, 
$\mathrm{df}=5)$, the size frequency distribution did $(\mathrm{KS}=0.1391$, $\mathrm{p}<0.01, \mathrm{n}=226$ ), but with no apparent pattern. Annual mean SCL ranged from $30.5 \mathrm{~cm}$ in 1996 ( $\mathrm{n}=26)$ to $36.7 \mathrm{~cm}$ in 2003 ( $\mathrm{n}=27$ ).

Kemp's ridley turtles ranged in size from 27.4 to $56.3 \mathrm{~cm} \mathrm{SCL}$, with a median of $42.2 \mathrm{~cm}$ and a mean of $42.3 \mathrm{~cm}$ ( $\mathrm{SD}=7.21, \mathrm{n}=67$ ) (Fig. 7). Mean size and the size distribution varied significantly among years (ANOVA, $F=2.8713, \mathrm{p}<0.05$, df $=5$; $\mathrm{KS}=$ $0.2059, \mathrm{p}<0.01, \mathrm{n}=67$ ), but with no apparent pattern. Annual mean SCL ranged from $38.4 \mathrm{~cm}$ in 2003 ( $\mathrm{n}=8$ ) to $44.6 \mathrm{~cm}$ in 2002 ( $\mathrm{n}=18$ ) (note that 1995 and 1996 are not included for this range since there were
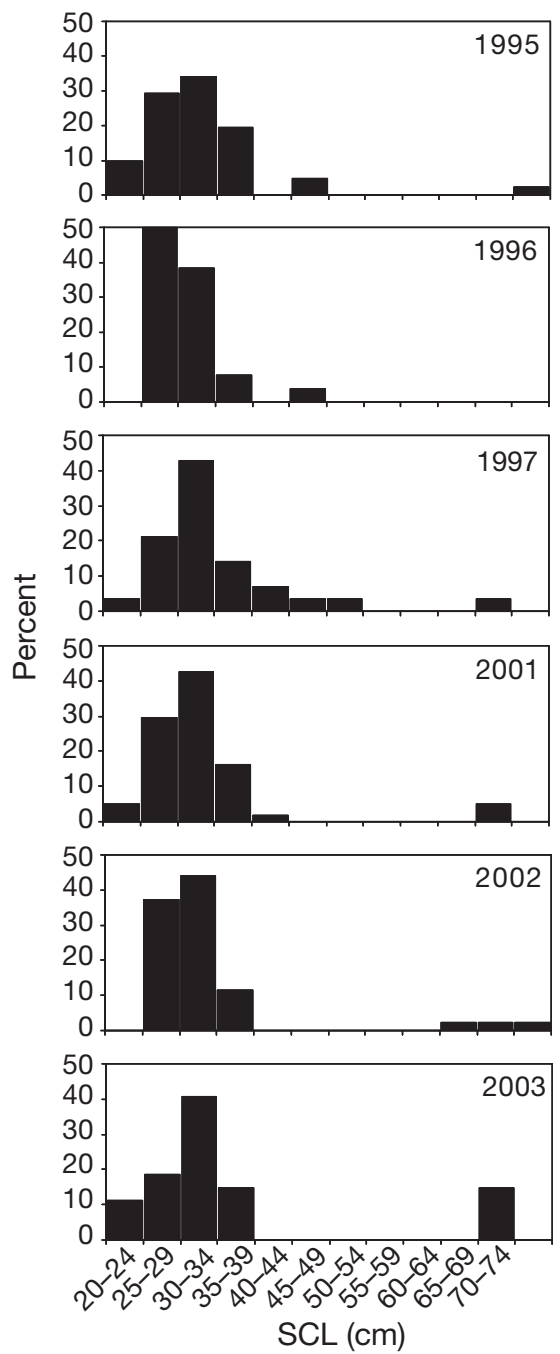

Fig. 6. Chelonia mydas. Annual size frequency distributions of green sea turtles captured in eastern Pamlico, Core, and Back sounds, $1995(\mathrm{n}=41), 1996(\mathrm{n}=26), 1997(\mathrm{n}=28), 2001$ $(\mathrm{n}=61), 2002(\mathrm{n}=43)$, and $2003(\mathrm{n}=27)$. Approximate average size of putative first time nesters (defined as unmarked turtles on beaches with saturation tagging, some of which may have been previously undetected nesters) is $100 \mathrm{~cm}$ (Zurita et al. 1993, L. M. Ehrhart unpubl. data). SCL: straight carapace length only 1 and 2 turtles measured in these years, respectively).

The mean CPUEs by year for loggerhead turtles ranged from 0.028 turtles per pound net-soak day ( 0.020 to $0.03995 \% \mathrm{CI}$ ) in 1995 to 0.062 turtles per pound net-soak day (0.048 to $0.08095 \%$ CI) in 2003 (Fig. 8a) and the CV for the annual CPUE estimates ranged from 0.11 to 0.16 . The mean CPUEs for green turtles ranged from 0.006 captures per pound net-soak day (0.004 to $0.00995 \% \mathrm{CI}$ ) in 1997 to 0.017 per pound net-soak day (0.010 to $0.02795 \%$ CI) in 2003 (Fig. 8b) and CVs ranged from 0.18 to 0.28 (mean $=0.23$ ). The mean CPUE for Kemp's ridley turtles ranged from

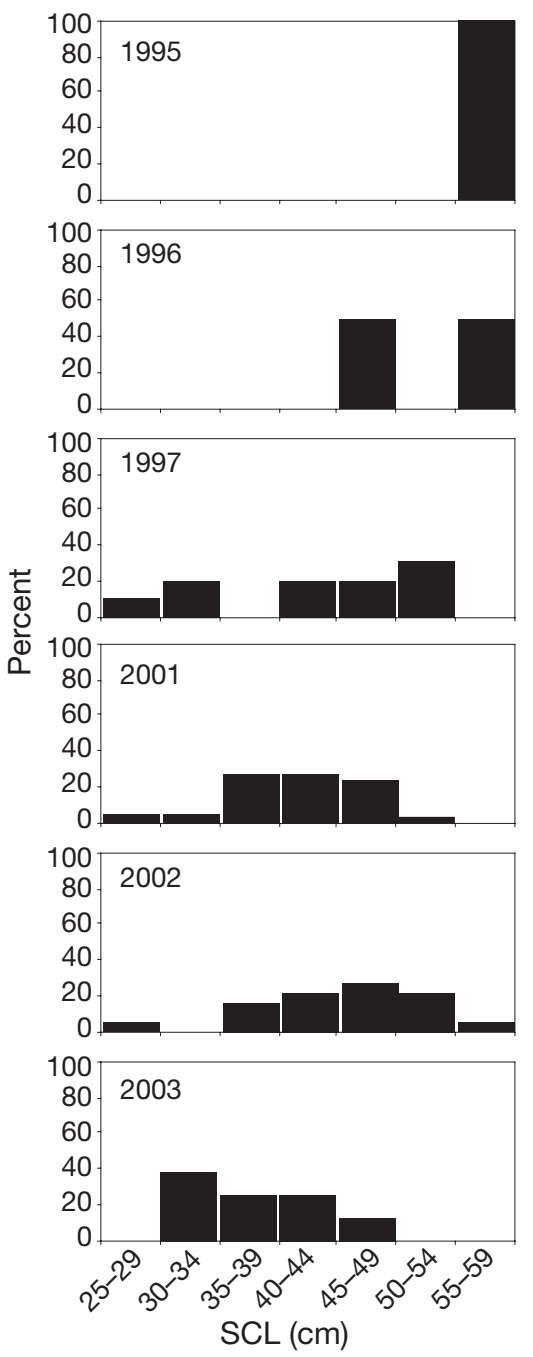

Fig. 7. Lepidochelys kempii. Annual size frequency distributions of Kemp's ridley sea turtles captured in eastern Pamlico, Core, and Back sounds, $1995(\mathrm{n}=1), 1996(\mathrm{n}=2), 1997$ ( $\mathrm{n}=$ 10), $2001(n=28), 2002(n=18)$, and $2003(n=8)$. Approximate average size of putative first time nesters (defined as unmarked turtles on beaches with saturation tagging, some of which may have been previously undetected nesters) is $60 \mathrm{~cm}$ (Turtle Expert Working Group 2000). SCL: straight carapace length 


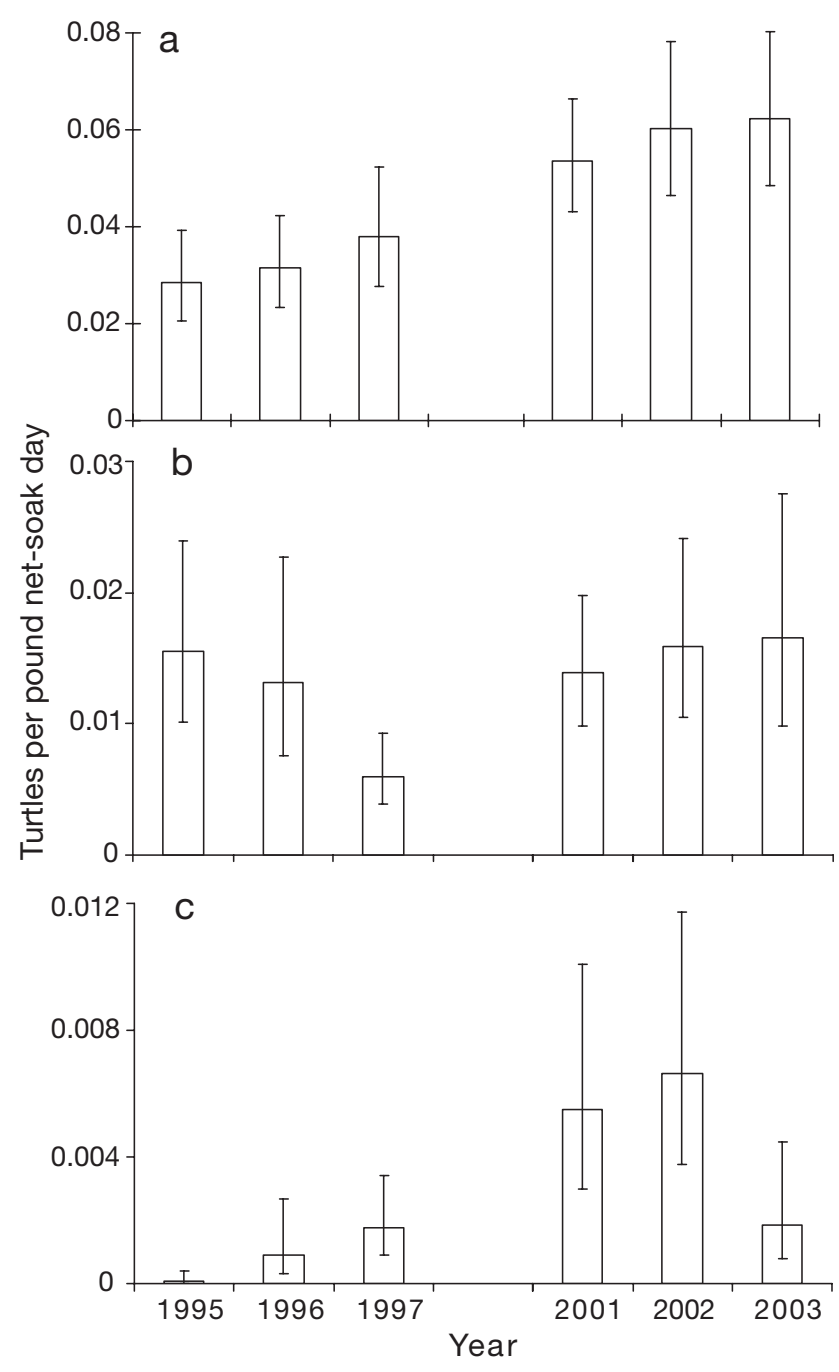

Fig. 8. Caretta caretta, Chelonia mydas, and Lepidochelys kempii. Estimated annual mean catch-per-unit-effort (CPUE) by year for (a) loggerhead, (b) green, and (c) Kemp's ridley sea turtles in eastern Pamlico, Core, and Back sounds, September to December 1995 to 1997 and 2001 to 2003. Bars indicate $\pm 95 \%$ confidence limits. Note the different scales on the $y$-axes

essentially zero $\left(7.72 \times 10^{-5} ; 1.15 \times 10^{-5}\right.$ to $3.95 \times 10^{-4}$ $95 \%$ CI) in 1995 to 0.007 captures per pound net-soak day (0.004 to $0.01295 \%$ CI) in 2002 (Fig. 8c) and the CVs ranged from 0.30 to 1.00 (mean $=0.51$ ).

We found a significant positive slope in the regression of mean annual CPUE versus time for loggerhead turtles, indicating a slow increase in loggerhead CPUE in the study area from 1995 to 2003 (CPUE $=-8.68+$ $0.0044 \times$ year, $\left.\mathrm{R}^{2}=0.99, \mathrm{p}<0.001\right)$. The slope, or annual rate of change of the CPUE was 0.0044 turtles per pound net-soak day $\left(1.67 \times 10^{-4} \mathrm{SE}\right)$ or $13.2 \%$. We did not detect significant linear trends in annual CPUEs for either Kemp's ridley $\left(\mathrm{R}^{2}=0.372, \mathrm{p}=0.118\right)$ or green turtles $\left(\mathrm{R}^{2}=0.015, \mathrm{p}=0.357\right)$ over the study period.

\section{DISCUSSION}

Sea turtles caught on the NC foraging grounds represent many age classes of both transient and resident animals and reflect both recruitment into the neritic foraging population and permanent emigration from it (Epperly et al.1995b, Avens et al. 2003, Sasso et al. 2006). Most were juveniles; older juveniles and adults were not well represented in our samples (Figs. 5 to 7 ). We would like to be able to extrapolate from trends in our CPUE estimates to trends in abundance of loggerhead sea turtle populations, but this would require making 2 major assumptions. The first is that changes in pound net catch rates reflect changes in loggerhead sea turtle abundance on the foraging grounds, implying that catch rates are proportional to abundance. Mark-recapture data often are used to estimate population sizes and thus provide an independent estimate of abundance. Unfortunately, our tag recaptures among years (11 of 863 loggerhead turtles were recaptured in a subsequent year) were too few and variable to effectively estimate population sizes or catchability coefficients or to provide an independent estimate of abundance.

Numerous studies in fisheries have demonstrated that catch rates and abundance often are not proportional (Hilborn \& Walters 1992, Harley et al. 2001) and a number of factors have been reported to affect catchability, the constant that relates abundance to CPUE (Paloheimo \& Dickie 1964, Rothschild 1977, Walters 2003, Maunder et al. 2006). These include variable efficiency of effort, species targeting, non-random and overlapping sampling effort, and environmental factors. As there were no changes in the fishing gear and how it was set and fished over the duration of our study, we do not think that fishing efficiency varied. Furthermore, sea turtles were not targeted by the fishery, and fishing effort was not determined by turtle catch rates (but could have been correlated with flounder catches). In addition, catchability could be related to effort, with a change in probability of capture being a function partly of the number of nets in the water. Other factors that can affect catchability may be of concern for our study. In the present study, the fixed nets were not placed randomly in the sounds, but were placed where fishing for flounder historically was productive. Thus, even though we selected the fishermen randomly and the turtles were caught passively, we did not sample the sound randomly. There is also a temporal effect that we did not address. Fishing effort and catch rates varied greatly within a season (Figs. 3a \& 4), likely due to environmental factors. Early in the season, before the onset of migration, turtle catch rates generally were low, and peaked later in the season, after which they declined as the turtles left the sounds. 
We pooled data within a season to calculate an annual CPUE, which means that the units of time (e.g. season) were likely not sufficiently small to assume that we effectively sampled the fishing season randomly (Walters 2003).

The second major assumption necessary to draw conclusions about trends in sea turtle populations based on our results is that the trends in CPUEs in the NC sounds represent the trends of the populations throughout their range. We are less sure about this assumption. Life history models for sea turtles, especially loggerheads, are evolving (e.g. Carr 1987, Witzell 2002, Bolten 2003). We now know that juvenile animals entering the neritic environment after an extended period in the oceanic environment do not always remain near the shore, but can shift between the 2 habitats (Keinath 1993, Witzell 2002, Mansfield 2006, McClellan \& Read 2007). Furthermore, movement by adults among habitats can be size dependent (Hawkes et al. 2006, Hatase et al. 2007). Only the neritic juvenile life stages are represented in our samples. It is not known what proportion of each population enters the sounds or if that proportion is constant among years, as transiency is high (Sasso et al. 2006). In fact, the shift in size frequencies of loggerhead turtles could indicate that we sampled a different segment of the population each year.

In the absence of independent estimates of abundance to validate our CPUEs as indices of abundance, we look to other study sites along the eastern coast of North America for evidence of similar trends. Loggerhead turtles were the most frequent species captured in our study (Table 1). The NC loggerhead foraging population is dominated by turtles originating in the south Florida nesting assemblage (estimated at $80 \%$ by Bass et al. 2004). The remainder of this foraging population comprises the northern subpopulation (NC to Northern Florida) (12\%), the Yucatán Peninsula (6\%), and other rookeries $(2 \%)$. The south Florida subpopulation was estimated to be increasing at $3.6 \% \mathrm{yr}^{-1}$ for the period 1981 to 1998 (Turtle Expert Working Group 2000), although in recent years the number of nests has declined (Florida Fish and Wildlife Conservation Commission 2006). The northern subpopulation, which is smaller than the south Florida assemblage by 1 order of magnitude, and as represented by surveys in South Carolina was declining at $3 \% \mathrm{yr}^{-1}$ from 1980 to 2002 (HopkinsMurphy et al. 2001, SCDNR 2006, S. Murphy pers. comm.). Nesting in Quintana Roo, Yucatán, was increasing 1987 to 2001 (Zurita et al. 2003), but has since decreased (J.C. Zurita pers. comm.). Thus, the NC foraging grounds represent a non-random composite of recruitment to the neritic juvenile population from all the aforementioned nesting assemblages (Bass et al. 2004, Bowen et al. 2004).
We observed a significant increase in loggerhead CPUE of $13.2 \% \mathrm{yr}^{-1}$ (Fig. 8) during the study period, along with a significant change in the size frequencies of loggerhead turtles, represented by a shift to larger individuals over the study period. Ehrhart et al. (2007) found a similar shift in the size frequency of loggerhead turtles in the Indian River Lagoon, Florida, since the early 1990s and, while they found no significant trend in CPUE over a 24 yr period, they did report a significant increase in CPUE over the last $4 \mathrm{yr}$ of their study (catch rates in 2002 to 2005 were about twice those from the earlier time periods). Sixty kilometers to the south of the Indian River Lagoon study site, at the St. Lucie Power Plant on Hutchinson Island, sea turtles are entrained with cooling water from the Atlantic Ocean into a canal system where they are net captured and released. The number of loggerhead captures at this site has increased at an average rate of more than $11 \% \mathrm{yr}^{-1}$ from 1988 to 2005, and a similar size shift was documented (M. Bresette pers. comm.). Lastly, shallow water trawl surveys off the southeastern coast of the USA from 1990 to 2005 also demonstrated the same size shift in loggerheads and an overall increase in sea turtle catch rates from 1990 to 2006 of about $5 \% \mathrm{yr}^{-1}$ (SCDNR unpubl., SEAMAP-SA data). In all 3 of these other study sites, loggerheads from the south Florida subpopulation also dominated the foraging populations (Witzell et al. 2002, Roberts et al. 2005, Reece et al. 2006). CPUE trends from our study, when combined with results of these other investigations, provide evidence for an increase in the recent past in neritic juvenile loggerhead abundance in the waters of the southeastern United States.

The shift in size reported for loggerhead turtles at all of these sites could represent the progression of a dominant age class through the population, a shift in size of recruitment from the oceanic environment, sampling of different portions of the foraging population, or a reduction in recruitment. If we assume that our CPUE estimates are proportional to abundance, an increasing trend in catch rates is inconsistent with a reduction in recruitment. We note that the 2 long-term studies in Florida indicate that the average sizes in the early 2000s were comparable to those in the early 1980s, with turtles captured in the early 1990s about 4 to $5 \mathrm{~cm}$ smaller (Ehrhart et al. 2007, M. Bresette pers. comm.). Thus, the observation of larger turtles in recent years represents a shift to what was observed 2 decades earlier.

Green turtles were the second most abundant species captured (Table 1). Bass et al. (2006) estimated that turtles from the east coast of the United States (54\%), Mexico (27\%), and Costa Rica (7\%) dominated the foraging population in the NC sounds. The remaining turtles likely originated in the South Atlantic. 
Recent estimates indicate that the 3 dominant nesting assemblages represented are increasing: Florida at $14 \% \mathrm{yr}^{-1}$ (Chaloupka et al. in press), Mexico at $11 \%$ $\mathrm{yr}^{-1}$ (A. Abreu pers. comm.), and Costa Rica at $5 \% \mathrm{yr}^{-1}$ (Troëng \& Rankin 2005, Chaloupka et al. in press).

Despite an estimated linear increase greater than $10 \% \mathrm{yr}^{-1}$ for the 2 most dominant green turtle nesting assemblages, we did not detect a significant trend in annual CPUEs of green turtles during 1995 to 2003. However, our statistical power (0.56) may not have been sufficient to detect a trend. A power analysis indicated that 8 sampling intervals (14 yr according to our sampling design) would be needed to detect an increasing linear trend of $10 \% \mathrm{yr}^{-1}$. In Florida, Ehrhart et al. (2007) did find a significant positive non-linear trend in green turtle CPUE for the period 1982 to 2005 in the Indian River Lagoon, which also is dominated by turtles originating from Florida, Costa Rica, and Mexico (Bagley 2003, Bolker et al. 2007). Indian River Lagoon green turtle CPUE increased exponentially $\sim 11 \% \mathrm{yr}^{-1}$ (937\% overall). Results from the nearby St. Lucie Power Plant are similar: capture rates for green turtles at this site (excluding recapture events) increased from a mean of 21.1 turtles $\mathrm{yr}^{-1}$ during 1977-1991 to a mean of 199.8 turtles $\mathrm{yr}^{-1}$ during 1992-2006 (M. Bressette pers. comm.). Ehrhart et al. (2007) did not find any shift in size among years, although there was seasonal variability. Bjorndal et al. (2005) used mark-recapture data to examine trends in abundance in the Bahamas, where the increasing Costa Rica nesting assemblage is the major source of green turtles (Lahanas et al. 1998), and found no significant overall trend. However, during a $24 \mathrm{yr}$ period at one location there were periods of significant trends (increasing followed by decreasing, and most recently stable or increasing).

Kemp's ridley turtles were the least frequent species captured (Table 1) and CVs of the annual CPUE estimates were the highest of all 3 species. This species nests in the western Gulf of Mexico, primarily on the beaches of Tamaulipas, and nest numbers have been increasing exponentially at a rate of 14 to $16 \% \mathrm{yr}^{-1}$ (Heppell et al. 2005). We caught more Kemp's ridley turtles during the latter $3 \mathrm{yr}$ of our study ( $\mathrm{n}=55)$, particularly in 2001 and 2002, than during the first $3 \mathrm{yr}$ ( $\mathrm{n}=15$ ) (Table 1), but because of so few captures the variability in our CPUE was high and our statistical power was low (0.27). Until 2003, the catch rates were increasing (Fig. 8), but the very low catch of turtles in 2003 rendered the overall relationship insignificant. Ten sampling intervals (19 yr) would be required to detect an exponential increase of $10 \% \mathrm{yr}^{-1}$ on the NC foraging grounds.

To date only a few sites have been established to monitor sea turtles while in the neritic environment of eastern North America, and most of those were not established for the purpose of estimating abundance. We suggest that there is a need for long-term studies of sea turtles on foraging grounds at multiple sites throughout their ranges to estimate stock sizes and to monitor trends in CPUE and catchability as an index of their abundance. Such synoptic studies will allow us to monitor the status of multiple subpopulations of juvenile sea turtles on the foraging grounds, well before the shifts in abundance would show up on the nesting beaches. However, like nesting beach data, the high variance and the low power to detect small trends, as found for 2 species in the NC foraging ground study, indicate that projects will require either many years of sampling or an increase in sampling effort within years, or both, to decrease CVs.

Acknowledgements. We gratefully acknowledge those who helped us with this project: L. Avens, J. Bell, R. Boettcher, B. Brown, W. Cluse, T. Cole, W. Crosby, T. Ellis, M. Godfrey, R. Goldman, A. Goodman, L. Goshe, K. Hart, W. Hettler, J. Keller, M. Kimball, S. Kubis, L. Leist, R. Mays, C. McClellan, N. McNeill G. Montgomery, E. Nichols, Z. Pettitt, A. Pierce, J. Scope, W. Shaw, M. Snover, M.A. Stamper, S. Varnam, J. Weaver, P. Whitfield, and T. Wholford for collecting sea turtle data; M. Cox, Tradewind Aviation, and AirCrews, Inc. for providing aerial census data. We appreciate the cooperation of all the commercial pound net fishermen who participated and we thank M. Bresette, L. Ehrhart, S. Murphy, P. Webster, and J. Zurita for providing us access to unpublished data and manuscripts. Thanks also to D. Ahrenholz, J. Bohnsack, A. Chester, L. Ehrhart, T. Ezard, R. King, C. Sasso, and anonymous reviewers for constructive comments. This research was conduced under the authority of US Endangered Species Act Section 10(a)(1)(A) scientific research permits from the US Fish and Wildlife Service (\#TE676379) and the National Marine Fisheries Service (\#1260). The National Marine Fisheries Service (NMFS) does not approve, recommend, or endorse any proprietary product or material mentioned in this article.

\section{LITERATURE CITED}

Avens L, Braun-McNeill J, Epperly S, Lohmann KJ (2003) Site fidelity and homing behavior in juvenile loggerhead sea turtles (Caretta caretta). Mar Biol 143:211-220

Bagley DA (2003) Characterizing juvenile green turtles (Chelonia mydas), from three east central Florida developmental habitats. MS thesis, University of Central Florida, Orlando, FL

Bass AL, Epperly S, Braun-McNeill J (2004) Multi-year analysis of stock composition of a loggerhead turtle (Caretta caretta) foraging habitat using maximum likelihood and Bayesian methods. Conserv Genet 5:783-796

Bass AL, Epperly SP, Braun-McNeill J (2006) Green turtle (Chelonia mydas) foraging and nesting aggregations in the Caribbean and Atlantic: impact of currents and behavior on dispersal. J Heredity 97:346-354

Bjorndal KA, Bolten AB, Chaloupka MY (2005) Evaluating trends in abundance of immature green turtles, Chelonia mydas, in the greater Caribbean. Ecol Appl 15:304-314

Bolker BM, Okuyama T, Bjorndal KA, Bolten AB (2007) In- 
corporating multiple mixed stocks in mixed stock analysis: 'many-to-many' analyses. Mol Ecol 16:685-695

Bolten AB (2003) Active swimmers-passive drifters: the oceanic juvenile stage of loggerheads in the Atlantic system. In: Bolten AB, Witherington BE (eds) Loggerhead sea turtles. Smithsonian Books, Washington, DC, p 63-78

Bolten AB, Bjorndal KA, Martins HR, Dellinger T, Biscoito MJ, Encalada SE, Bowen BW (1998) Transatlantic developmental migrations of loggerhead sea turtles demonstrated by mtDNA sequence analysis. Ecol Appl 8:1-7

Bowen BW, Bass AL, Chow SM, Bostrom M and 15 others (2004) Natal homing in juvenile loggerhead turtles (Caretta caretta). Mol Ecol 13:3797-3808

Braun-McNeill J, Avens L, Epperly SP (2003) Estimated tag retention rates for PIT and inconel tags in juvenile loggerhead (Caretta caretta) sea turtles. In: Seminoff JA (compiler) Proceedings of the 22nd Annual Symposium on Sea Turtle Biology and Conservation. NOAA Tech Mem NMFS-SEFSC-503:104. Available at: www.seaturtle.org/ ists/proceedings.php\#26

Braun-McNeill J, Epperly SP, Owens DW, Avens L Williams E, Harms CA (2007) Seasonal reliability of testosterone radioimmunoassay (RIA) for predicting sex ratios of juvenile loggerhead (Caretta caretta) turtles. Herpetologica 63(3):275-284

Broderick D, Moritz C, Miller JD, Guinea M, Prince RJ, Limpus CJ (1994) Genetic studies of the hawksbill turtle: evidence for multiple stocks and mixed feeding grounds in Australian waters. Pac Conserv Biol 1:123-131

Carr A (1987) New perspectives on the pelagic stage of sea turtle development. Conserv Biol 1:103-121

Chaloupka M, Limpus C (2001) Trends in abundance of sea turtles resident in southern Great Barrier Reef waters. Biol Conserv 102:235-249

Chaloupka M, Bjorndal KA, Balazs GH, Bolten AB, Ehrhart LM, Limpus CJ, Suganuma H, Troëng S, Yamaguchi M (in press) Encouraging outlook for recovery of a onceseverely-exploited marine megaherbivore and restoration of its ecological function. Global Ecol Biogeogr

Ehrhart LM, Redfoot WE, Bagley DA (2007) Marine turtles of the central region of the Indian River Lagoon system. Fla Sci (in press)

Epperly SP, Braun J, Chester AJ (1995a) Aerial surveys for sea turtles in North Carolina inshore waters. Fish Bull 93: $254-261$

Epperly SP, Braun J, Veishlow A (1995b) Sea turtles in North Carolina waters. Conserv Biol 9:384-394

Florida Fish and Wildlife Conservation Commission (2006) Long-term monitoring program reveals a decline in Florida loggerhead sea turtle nesting. Fish and Wildlife Research Institute, Florida Fish and Wildlife Conservation Commission, St. Petersburg, FL. Available at: http:// research.myfwc.com/features/view_article.asp?id=27537

Gerrodette T (1987) A power analysis for detecting trends. Ecology 68:1364-1372

Gerrodette T (1993) Trends: software for a power analysis of linear regression. Wildl Soc Bull 21:515-516

Goode GB (1887) The fisheries and fishery industries of the United States. History and methods of the fisheries, Section V, Government Printing Office, Washington, DC, 255 plates. available at: http://celebrating200years.nooa. gov/rarebooks/fisheries/welcome.html

Gross MG (1972) Oceanography. A view of the earth. Prentice-Hall, Englewood Cliffs, NJ

Harley SJ, Myers RA, Dunn A (2001) Is catch-per-unit effort proportional to abundance? Can J Fish Aquat Sci 58: 1760-1772
Hatase H, Omuta K, Tsukamoto K (2007) Bottom or midwater: alternative foraging behaviors in adult female loggerhead sea turtles. J Zool 273:46-55

Hawkes LA, Broderick AC, Coyne MS, Godfrey MH and 5 others (2006) Phenotypically linked dichotomy in sea turtle foraging requires multiple conservation approaches. Curr Biol 16:990-995

Heppell SS, Crouse DT, Crowder LB, Epperly SP, Gabriel W, Henwood T, Márquez R, Thompson NB (2005) A population model to estimate recovery time, population size, and management impacts on Kemp's ridley sea turtles. Chelonian Conserv Biol 4:767-773

Higgins E, Pearson JC (1928) Examination of the summer fisheries of Pamlico and Core Sounds, N.C., with special reference to the destruction of undersized fish and the protection of the gray trout Cynoscion regalis (Block and Schneider). In: Report of the United States Commissioner of Fisheries for the Fiscal Year 1927 with Appendices. US Dept of Commerce, Bureau of Fisheries, Government Printing Office, Washington, DC, p 20-65 http://docs.lib.noaa.gov/rescue/ cof/data_rescue_fish_commission_annual_reports.html

Hilborn R, Walters CJ (1992) Quantitative fisheries stock assessment: choice, dynamics and uncertainty. Chapman \& Hall, New York

Hopkins-Murphy SR, Murphy TM, Hope CP, Coker JW, Hoyle ME (2001) Population trends and nesting distribution of the loggerhead turtle (Caretta caretta) in South Carolina, 1980-1997. Final completion report to the US Fish and Wildlife Service, E-1-21. South Carolina Department of Natural Resources, Marine Turtle Conservation Program, Charleston, SC

IUCN (International Union for Conservation of Nature and Natural Resources) (2006) IUCN redlist of threatened species. The Conservation Union, Cambridge. Available at: www.redlist.org

Keinath JL (1993) Movements and behavior of wild and headstarted turtles. PhD dissertation, The College of William and Mary in Virginia, Williamsburg, VA

Lahanas PN, Bjorndal KA, Bolten AB, Encalada SE, Miyamoto MM, Valverde RA, Bowen BW (1998) Genetic composition of a green turtle (Chelonia mydas) feeding ground population: evidence for multiple origins. Mar Biol 130:345-352

Leon YM, Diez CE (1999) Population structure of hawksbill turtles on a foraging ground in the Dominican Republic. Chelonian Conserv Biol 3:230-236

Mansfield KL (2006) Sources of mortality, movements and behavior of sea turtles in Virginia. PhD dissertation, The College of William and Mary in Virginia, Williamsburg, VA

Maunder MN, Sibert JR, Fonteneau A, Hamton J, Kleiber P, Harley SJ (2006) Interpreting catch per unit effort data to assess the status of individual stocks and communities. ICES J Mar Sci 63:1373-1385

McClellan CM, Read A (2007) Complexity and variation in loggerhead sea turtle life history. Biol Lett doi: 10.1098/ rbl.2007.0355

NCDMF (North Carolina Division of Marine Fisheries) (2007) North Carolina fishery management plan. Albemarle Sound area. River herring. NCDMF, Morehead City, NC, p 1-311. Available at: www.ncdmf.net/fmps/index.html

NCDMF (North Carolina Division of Marine Fisheries) (2007) North Carolina fishery management plan. Southern flounder (Paralichthys lethostigma). NCDMF, Morehead City, NC, p 1-335. Available at: www.ncdmf.net/fmps/ index.html

North Carolina Marine Fisheries Commission (2007) North Carolina rules for coastal waters. NCDMF, Morehead City, NC, p 1-220. Available at: www.ncdmf.net/fmps/index.html 
NMFS SEFSC (National Marine Fisheries Service Southeast Fisheries Science Center) (2001) Stock assessments of loggerhead and leatherback sea turtles and an assessment of the impact of the pelagic longline fishery on loggerhead and leatherback sea turtles of the Western North Atlantic. NOAA Tech Mem NMFS-SEFSC-455:1-343. Available at: www.sefsc.noaa.gov/seaturtletechmemos.jsp

Paloheimo JE, Dickie LM (1964) Abundance and fishing success. Rapp PV Réun Cons Int Exlor Mer 155:152-163

Pennington M (1983) Efficient estimators of abundance for fish and plankton surveys. Biometrics 39:281-286

Reece JS, Ehrhart LM, Parkinson CL (2006) Mixed stock analysis of juvenile loggerheads (Caretta caretta) in Indian River Lagoon, Florida: implications for conservation planning. Conserv Genet 7:345-352

Roberts MA, Anderson CJ, Stender B, Segars A, Whittaker JD, Grady JM, Quattro JM (2005) Estimated contribution of Atlantic coastal loggerhead turtle nesting populations to offshore feeding aggregations. Conserv Genet 6: 133-139

Ross SW, Epperly SP (1985) Utilization of shallow estuarine nursery areas by fishes in Pamlico Sound, North Carolina and adjacent tributaries. In: Yanez-Arancibia A (ed) Fish community ecology in estuaries and coastal lagoons. Towards an ecosystem integration. Universidad de Mexico, Mexico City, p 207-232

Rothschild BJ (1977) Fishing effort. In: Gulland JA (ed) Fish population dynamics. John Wiley \& Sons, New York, p 96-115

Sasso CR, Braun-McNeill J, Avens L, Epperly SP (2006) Effects of transients on estimating survival and population growth in juvenile loggerhead turtles. Mar Ecol Prog Ser 324:287-292

SCDNR (South Carolina Department of Natural Resources) (2006) Loggerhead nesting index. SCDNR Marine Turtle Conservation Program, Charleston, SC. Available at: www.dnr.sc.gov/seaturtle/lhni.htm

Sears CJ, Bowen BW, Chapman RW, Galloway SB, HopkinsMurphy SR, Woodley CM (1995) Demographic composition of the feeding population of juvenile loggerhead sea

Editorial responsibility: Dave Hodgson, University of Exeter, Cornwall Campus, UK turtles (Caretta caretta) off Charleston, South Carolina: evidence from mitochondrial DNA markers. Mar Biol 123:869-874

Troëng S, Rankin E (2005) Long term conservation efforts contribute to positive green turtle Chelonia mydas nesting trend at Tortuguero, Costa Rica. Biol Conserv 121: $111-116$

True FW (1887) Part XI. The pound-net fisheries of the Atlantic states. In: Goode GB (ed) The fisheries and fishery industries of the United States, Vol I. Government Printing Office, Washington, DC, p 595-609. available at: http://celebrating200years.nooa.gov/rarebooks/fisheries/ welcome.html

Turtle Expert Working Group (2000) Assessment update for the Kemp's ridley and loggerhead sea turtle populations in the western North Atlantic. NOAA Tech Mem NMFSSEFSC-444:1-115. Available at: www.sefsc.noaa.gov/seaturtletechmemos.jsp

Walters C (2003) Folly and fantasy in the analysis of spatial catch rate data. Can J Fish Aquat Sci 60:1433-1436

Witzell WN (2002) Immature Atlantic loggerhead turtles (Caretta caretta): suggested changes to the life history model. Herpetol Rev 33:266-269

Witzell WN, Bass AL, Bresette MJ, Singewald DA, Gorham JC (2002) Origin of immature loggerhead sea turtles (Caretta caretta) at Hutchinson Island, Florida: evidence from mtDNA markers. Fish Bull 100:624-631

Zurita JC, Herrera R, Prezas B (1993) Tortugas marinas del Caribe. In: Salazar-Vallejo SI, Gonzalez NE (eds) Biodiversidad marina y costera de México. Comisión Nacional para el Conocimiento y Aprovechamiento de la Biodiversidad and Centro de Investigactiones de Quintana Roo, Chetumal, p 735-751

Zurita JC, Herrera R, Arenas A, Torres ME, Calderón C, Gómez L, Alvarado JC, Villavicencio R (2003) Nesting loggerhead and green sea turtles in Quintana Roo, Mexico. In: Seminoff JA (compiler) Proceedings of the 22nd Annual Symposium on Sea Turtle Biology and Conservation. NOAA Tech Mem NMFS-SEFSC-503:125-127. Available at: www.seaturtle.org/ists/proceedings.php\#26

Submitted: November 14, 2006; Accepted: September 11, 2007 Proofs received from author(s): September 27, 2007 